\title{
LÉZERES FELMÉRŐESZKÖZ ÉS FELMÉRÉSI MÓDSZERTAN KÖZVETLEN ÉPÍTÉSZETI TERVEZŐSZOFTVER- KAPCSOLATTAL
}

\section{LASER SURVEY TOOL AND SURVEY METHODOLOGY FOR DIRECT ARCHITECTURAL CAD SOFTWARE CONNECTION}

\author{
Máder Patrik Márk, ${ }^{1}$ Szilágyi Dorottya, ${ }^{2}$ Rák Olivér, ${ }^{3}$ Háber István Ervin ${ }^{4}$ \\ Pécsi Tudományegyetem Müszaki és Informatikai Kar, Pécs, Magyarország \\ ${ }^{1}$ patrik.mader@mik.pte.hu \\ 2szdo95@gmail.com \\ ${ }^{3}$ rakoliver90@gmail.com \\ ${ }^{4}$ ihaber@mik.pte.hu
}

\begin{abstract}
Building Information Modeling (BIM) has been the fastest growing methodology in architectural design, construction, preliminary works and in several other engineering activities in the past few years. It is mostly implemented in the fields of design, construction and building operation, however, there are still unexploited possibilities in further areas - such as building surveys. Many tools are available today to produce detailed and accurate 3D survey data, but specialists and custom software usually have to be involved in the process. Transforming this information into BIM models is also a time-consuming task, as their direct architectural design software integration is limited. The following article introduces a possible solution in order to improve communication and the modeling process.
\end{abstract}

Keywords: building survey, algorithm, building information modeling, 3D printing.

\section{Összefoglalás}

Az épületinformációs modellezés (BIM) az építészeti tervezés, kivitelezés, műszaki előkészítés és egyéb mérnöki tevékenységek esetén is az elmúlt évek legnagyobb ütemben fejlődő módszertana. Integrációja talán leginkább a tervezés, a kivitelezés és az üzemeltetés területein valósult meg, azonban még számos terület, például az építészeti felmérés is biztosít lehetőségeket. Jelenleg is számtalan eszközzel készíthető részletes és pontos 3D-felmérési állomány, azonban ezek feldolgozása többnyire egyedi szoftverekben és specialisták bevonásával valósul meg. BIM-modellé alakításuk is időigényes manuális feladat, mivel közvetlen építészeti tervezőszoftver-integrációjuk nagyon korlátozott. A cikk egy lehetséges megoldást mutat be a hatékony kommunikáció megteremtése és a modellezési folyamat tovább fejlesztése érdekében.

Kulcsszavak: épületfelmérés, algoritmus, épületinformációs modellezés, 3D nyomtatás.

\section{Bevezető}

Építészeti felmérésre a tervezés-előkészítő felméréstől kezdve, az építés közben elvégzett ellenőrző méréseken és az aktuális állapotok rögzítésén keresztül, egy egyszerű belső tér falainak átfestéséhez szükséges anyagmennyiség-meghatározásig minden esetben sor kerül.

A hosszú ideje alkalmazott hagyományos eszközök (pl.: mérőszalag, lézeres távolságmérő) mellett manapság korszerű technológiák (pl.: lézerszkennerek, fotogrammetriai elven müködő 
eszközök) is támogatják a mérnöki munkát [1]. A modern eszközöknek köszönhetően jelenleg minden eddiginél pontosabb és részletgazdagabb 3 dimenziós állományok előállítására és megjelenítésére nyílik lehetőség.

A folyamat hatékonysága azonban csak a felmérés céljának megfelelően kiválasztott felmérőeszköz és módszertan esetén biztosítható. Több gyártó kínál szinte minden elérhető funkciót egy eszközben vagy ráépülő eszközkörnyezetben felsorakoztató termékeket (pl. Leica RTC360 lézerszkenner és LeicaCyclone szoftver, vagy Leica BLK360 lézerszkenner [2] és OrthoGraph szoftver [3]), azonban ezek használata és az előállított állományok utófeldolgozása magas szakértelmet kíván, beszerzési áruk pedig magas tartományban mozog. Ezzel szemben sok eszköz rendelkezik ezekhez képest korlátozott funkcionalitással (pl.: LeicaDisto professzionális lézeres távolságmérő termékcsalád [2]), amelyhez alacsonyabb felhasználói kompetenciaigény és ár társul.

Kijelenthető, hogy mindkét esetben kompromisszumok megkötése szükséges, viszont véleményünk szerint a két kategória közelíthető egymáshoz, és a saját szoftverkörnyezet helyett a magasabb funkcionalitást biztosító építészeti tervezőszoftverekkel történő szoros együttmüködés is biztosítható.

\section{Koncepció, kialakítás, felépítés}

Az eszközfejlesztési alapkoncepció megfogalmazása során a bevezetőben röviden feltárt tényezők és szempontok kerültek figyelembevételre. A cél egy olyan eszköz kialakítása, amely a gyakorlatias felhasználás, a 3D-építészeti felújítás és továbbtervezés lehetőségének megteremtését kívánja kiszolgálni egyszerü eszközkezelés és a felmérési adatok automatizált utófeldolgozásának segítségével. A felmérési adatok algoritmus segítségével 3D-épületmodellekké, épületrészmodellekké állnak össze a tervezőszoftverek natív környezetében. A műszer kialakítása tulajdonképpen a földi lézerszkennerek (TLS) [4] müködési elvén alapul, annak egyszerűsített megvalósításával. Egy lézermodul segítségével felületenként vagy élek mentén néhány pont mérését követően egy „ultraritka pontfelhő” állítható elő, amely egy feldolgozó algoritmus segítségével építészeti tervezőszoftverekben is értelmezhető modellelemekké konvertálható.

A fejlesztési tevékenység jelenleg a második változat megvalósításánál tart. Korábban az Emberi Erőforrások Minisztériuma, Emberi Erőforrás Tá- mogatáskezelő „NTP-NFTÖ-18” azonosítójú „Nemzet Fiatal Tehetségeiért Ösztöndíj” című pályázata lehetőséget biztosított az elképzelés létjogosultságának tesztelésére és az első termékverzió elkészítésére. A fejlesztési folyamat során azonban felmerültek módosítható, javítható részletek, melyek a jelenlegi munkafázisban kerülhettek kidolgozásra.

A fejlesztési fázis a korábbi folyamat során elkészült eszközváz, vezérlőelektronika és a funkcionalitásért felelős programsorok felülvizsgálatával kezdődött. A vizsgálat rávilágított arra, hogy a meglévő részletek javítása nem eredményezi az elvárt előrelépést, így a teljes projekt a korábbi tapasztalatokat felhasználva újra tervezésre került. A korábbi hardveralkotók (motorok, szenzorok, modulok) teljes körű cseréje, az eszközváz áttervezése és 3D-nyomtatása, valamint a programsorok újraírása is megtörtént.

A vezérlőelektronika alapegységét továbbra is az Arduino-környezet [5] biztosítja. Hardvere azonban a korábbi Arduino Uno R3-eszközt felváltva egy speciális (RobotDyn) Arduino Mega2560-alaplap, amely integrált ESP8266 Wi-Fi-modullal rendelkezik. (2. ábra - „A”) Ez a konstrukció lehetőséget biztosít Wi-Fi-protokollon keresztüli vezetéknélküli kommunikációra, a lézermodul és minden egyéb kiegészítőegység kezelésére, valamint a motorvezérlő modul (2. ábra - „B”) csatlakoztatását követően a léptetőmotorok szabályozására is (1. ábra).

A léptetőmotorok (2. ábra - „C”) hagyományos, alacsony áramerősség-igényű (0,4 A), NEMA 17-típusú egységek, amelyek az XY tengely körüli 360 fokos forgatásért és YZ tengely-irányú lézermodul mozgatásért felelősek. Utóbbi esetében a hasznosítható tartomány lefedésére 98 fok elfordulás elegendő, így forgástartománya szoftveresen korlátozott.

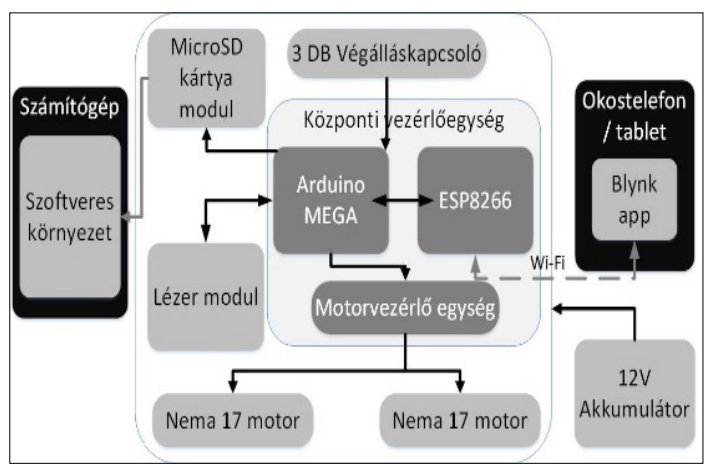

1. ábra. A kialakítás logikai vázrajza 


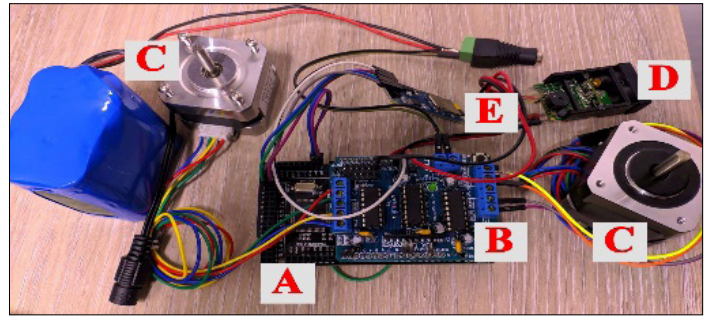

2. ábra. A rendszer fizikai felépítése

A beépített lézeregység (2. ábra - „D”) hagyományos lézeres távolságmérőkben is megtalálható típusokkal egyenértékü. (2. ábra) Vezérlése kommunikációs portjain keresztül, egyszerü karakteres utasítások segítségével lehetséges. Ilyen például a „D”, amely parancs kiadása esetén a modul egy mérést végez, vagy az „S”, amelyet követően kiolvassa a feszültség- és aktuálishőmérséklet-adatokat. Az Arduino alaplappal történő kommunikáció során is ezek segítségével valósul meg az utasítások kezelése.

\section{Müködési mechanizmus}

A mérési folyamat okostelefon vagy tablet segítségével végrehajtott pozicionálással kezdődik. Mobilapplikáció [6] segítségével létrehozható a vezérlést és a visszajelzést biztosító környezet (3. ábra), amely Wi-Fi-protokoll segítségével kapcsolódik a felmérőegységhez, és küldi számára az utasításokat. A műszer lehelyezését követően a felmérni kívánt pont pozícióját beállítva kiválasztandó a felmérendő épületszerkezet típusa, majd aktiválható a lézermodul, és elvégezhető a mérés. A felületről visszaverődő lézersugár segítségével megállapítható az egység és a felmért pont távolsága. A mért érték megjelenik az applikációban, és tárolásra kerül az eszközbe helyezett microSD (2. ábra - „E”) kártyán is. Egybefüggő sík felületek esetén az eddig ismertetett folyamat még legalább két alkalommal hajtandó végre, ezzel biztosítva, hogy minden felületről minimum 3 db mérési pont álljon rendelkezésre, amely már

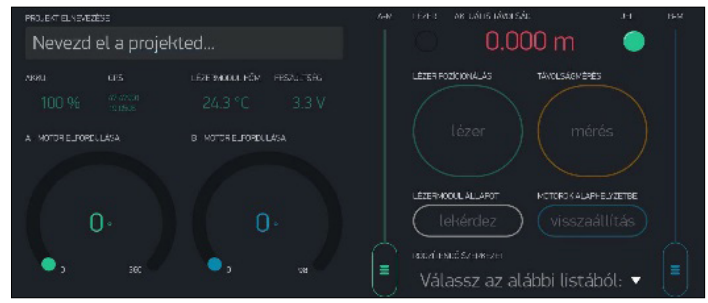

3. ábra. Az irányítópult felépítése egyértelműen meghatározza a síkokat. Amennyiben nem felületi, hanem alaki mérést szeretnénk elvégezni, a megírt programsorok erre is biztosítanak lehetőséget. Alaki mérés alatt a szerkezetek és tárgyak befoglaló geometriájának rögzítése értendő a jellemző pontjaik felmérése által.

A mért távolságokat és egyéb kiegészítő, valamint egyedi azonosító információkat az eszköz folyamatosan microSD kártyára is rögzíti. Az adatok struktúrájának kialakítása során egyszerű váz megalkotása volt a cél, amely a későbbi felhasználást teljes egészében ki tudja szolgálni, és megfelelő alapot biztosít a koordinátaszámítás műveleteihez.

$\mathrm{Az}$ adatmenedzsment folyamatához tartozik a mérés során keletkező adatokból a mért pontok koordinátáinak számítása és csoportosítása is. Ennek környezete jelenleg egy komplex táblázatban biztosított. A műveletek során az eszköz pozíciója tekinthető az alappontnak $(0,0,0)$, amelyhez viszonyítva egy relatív koordinátarendszerben kerülnek rögzítésre a felmért pontok. Mivel ez esetben a távolság, az elfordulásértékek és az alappont („origó”) mindhárom koordinátája ismert, $(0,0,0)$ trigonometrikus függvények, szögfüggvények segítségével meghatározható a másik pont térbeli helyzete. A pontok térbeli pozíciója az algoritmusalapú feldolgozás alapja, így a számítás helyessége létfontosságú. Ennek érdekében minden mérést követően a 2 db (P1, P2) térbeli pont távolságának meghatározására [7] alkalmas képlet visszaellenőrzési céllal felhasználásra kerül (1).

$$
d\left(P_{1}, P_{2}\right)=\sqrt{(x 2-x 1)^{2}+(y 2-y 1)^{2}+(z 2-z 1)^{2}}
$$

A koordinátaszámítást követő utolsó lépésben a tervezőszoftverek számára is értelmezhető geometriák előállítása történik. Az elkészített algoritmus Autodesk Revit tervezőszoftver Dynamo-kiegészítőjében került összeállításra. Az algoritmus a koordinátaszámítást végző táblázat releváns adatainak felhasználásával a felmérés eredményének vizualizálását és a pontok által alkotott felületek épületszerkezeteknek (falak, födémek, ablakok, ajtók, stb.) való megfeleltetését végzi el. A programsorok az adatok feldolgozása során felmérési típusazonosító alapján megkülönböztetik az információkat, így például a nyílászárókat $4 \mathrm{db}$ sarokpontjuk felhasználásával képezik le, míg az egyszerü falak és födémek minimum $3 \mathrm{db}$ mérési pontra feszített síkon kerülnek elhelyezésre.

A teljes folyamat automatikus, és a végtermékek a tervezőszoftver számára natív modellele- 
mekként azonosított, információtartalommal is bíró BIM-entitások, amelyek a programfunkciókat kihasználva a későbbiekben módosíthatók is (4. ábra).

Több helyiség felmérése vagy több álláspont esetén az egymáshoz illesztés minden esetben $3 \mathrm{db}$ segédpont felhasználásával lehetséges. Ezeket a referenciapontokat a szerkezetek azonosításával megegyező módon egyedi azonosítóval rögzítjük.

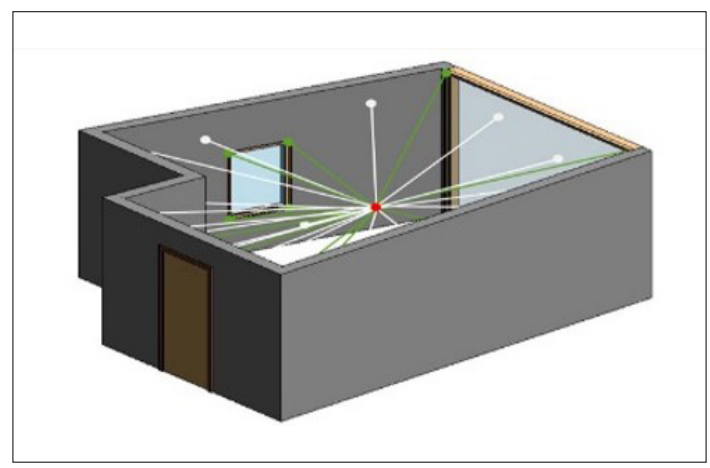

4. ábra. Az algoritmus által generált 3D-modell

\section{Eszközváz}

A prototípusgyártás fontos részét képezi a külső burok megtervezése és gyártása is. A vázmodellek és az alkotórészek előállítása 3D modellező szoftverekben történik, melyek ezt követően Polylactic Acid (PLA) anyagból 3D nyomtató segítségével készültek el. Ezzel a munkafolyamattal a koncepcióvázlatok rövid idő alatt újra tervezhetők, módosíthatók és előállíthatók (5. ábra).

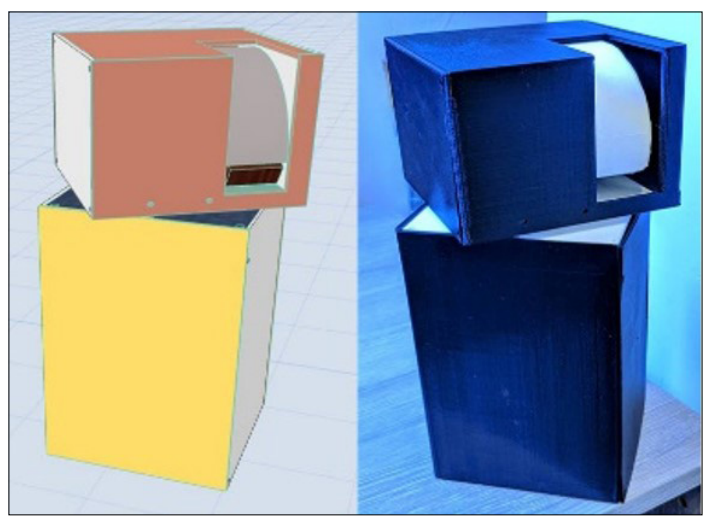

5. ábra. A modell és az összeszerelt mérőmüszer

\section{Következtetések}

A felmérőeszköz és a módszertan is egyaránt teljesíti az előirányzott elképzeléseket, így a kutatásfejlesztési tevékenység eredményei pozitívnak és biztatónak nevezhetők. A tervezőszoftverrel való közvetlen kapcsolata növeli a müszer felhasználóinak körét, és hatékonyabb, gazdaságosabb folyamatokat eredményez. Akár amatőr felhasználók is elvégezhetik épületük egyszerüsített belső felmérését. Az ennek során előállított állományok pedig az építészek számára biztosítanak kiindulási 3D-modellt, amely a tovább tervezés alapjaként felhasználható. Ezek alapján indokoltnak tartjuk a műszer további optimalizációját és bővített funkcionalitására irányuló jövőbeli fejlesztési lehetőségek megvalósítását. Többek között a mérési folyamat automatizálása, az adatok mobileszközön történő azonnali vizualizációja és más tervezőszoftverekbe történő integrációja számos kihívást tartogat még.

\section{Köszönetnyilvánítás}

Az Innovációs és Technológiai Minisztérium ÚNKP19-3 kódszámú Új Nemzeti Kiválóság Programjának szakmai támogatásával készült.

\section{Szakirodalmi hivatkozások}

[1] Bayyati A.: Modern Surveying Technology: availability and suitability for Heritage Building Surveying and Heritage Building Information Models (HerBIM). London South Bank University, (2017) 2-7.

[2] Leica Geosystems, Termékek (letöltve: 2020. február 2.).

https://leica-geosystems.com/hu-hu/products

[3] OrthoGraph Enterprise (letöltve: 2020. január 20.) https://www.orthograph.com/

[4] Petrie G., Toth K. C.: Terrestrial Laser Scanners. In: Topographic Laser Ranging and Scanning, Principles and Processing. (Szerk.: Shan J., Toth K. C.). Taylor \& Francis, CRC Press, 2009. 87-92.

[5] Arduino: What is Arduino? (letöltve: 2020. január 20.).

https://www.arduino.cc/en/Guide/Introduction

[6] Blynk: Miből áll és hogyan is müködik a Blynk? (letöltve: 2020. január 20.).

http://docs.blynk.cc/\#intro

[7] Soo T.: Coordinate Systems and Vectors in 3-Space. In: Single Variable Calculus: Early Transcendentals. $1^{\text {st }}$ Edition (Szerk.: Soo T.), Cengage Learning, 2010. 911. 